\title{
VILJAKASKAAN (CALLIGYPONA PELLUCIDA F.) AIHEUTTAMAN KAURANTUHON VAIKUTUS KAURAN VILJELYALAAN JA SATOI- HIN SUOMESSA
}

\author{
Mikko Raatikainen ja Aulis Tinnilä \\ Maatalouden tutkimuskeskus, Tuhoeläintutkimuslaitos, Tikkurila
}

Saapunut 25. 10. 1958.

Suomen läntisen rannikkoalueen kauranviljelyä useina viime vuosina rasittanutta tuhoa ja sen selvittämiseksi suoritettuja tutkimuksia on aikaisemmin käsitelty useissa julkaisuissa (vrt. 1-11, 13 ja 14). Seuraavassa käsitellään Tuhoeläintutkimuslaitoksen tutkimustulosten, viljelijöiltä saatujen tietojen sekä maataloudellisten tilastojen avulla seikkoja, jotka näyttävät vaikuttaneen kaurantuhon leviämiseen ja voimakkuuteen sekä tuhosta johtuviin seurausilmiöihin peltokasvien viljelyaloissa.

\section{Kaurantuho ja sen aiheuttaja}

Kaurantuhon aiheuttajaksi on todettu viljakaskas Calligypona (Delphacodes) pellucida F. KANERvo et al. (10) ovat kuvanneet aikaisemmin sen aiheuttamia symptomeja kaurassa. Tyypillistä tuholle ovat eriasteisesti vioittuneet kaurayksilöt (kuva 1). Syynä tähän näyttää olevan etupäässä kaskaiden ryhmittyminen ja tällaisten ryhmien pysyvyys kasvuston tietyissä kaurayksiköissä, jotka tuhoutuvat sitä pahemmin mitä aikaisemmassa kauran kehitysvaiheessa, mitä useampi ja mitä pitemmän aikaa kaskas on kasviin vaikuttanut.

Symptomeissa on todettu vaihteluja eri kasvupaikoilla ja eri vuosina. Niinpä v. 1957 viljakaskaiden vioittaman kauran väritys oli lievemmin kellanruskea tai -punainen, vesominen vähäisempi ja sato parempi kuin edellisenä vuonna, vaikka kaskaiden määrä ja vaikutusaika kaurayksilöä kohden eräissä havaintopaikoissa on ollut jokseenkin sama molempina vuosina. Sama todettiin myös eristyshäkkikokeissa.

Sisä-Suomesta mainitaan (6-9 ja 13) samankaltaista kauran heikkoa kasvua, mutta sikäläisen tuhon aiheuttajasta tai aiheuttajista ei kuitenkaan ole toistaiseksi tarkkoja tietoja. 
Viljakaskasta esiintyy ainakin koko Suomen viljanviljelyalueella, mutta kokeellisesti ei ole todettu, että muut kuin tuhoalueen kaskaat saisivat aikaan kaurantuhoa (10). NuoRTEvan (11) tutkimusten mukaan sisältää tuhoalueen (Sulva, Laihia) kaskaiden sylki melkoisesti enemmän kasvua estäviä aineita kuin tuhoalueen ulkopuolisten (Bromarf) kaskaiden sylki. Viljakaskas elää heinäkasveja kasvavissa biotoopeissa kuten viljapelloissa, heinänurmissa, kulttuuri- ja

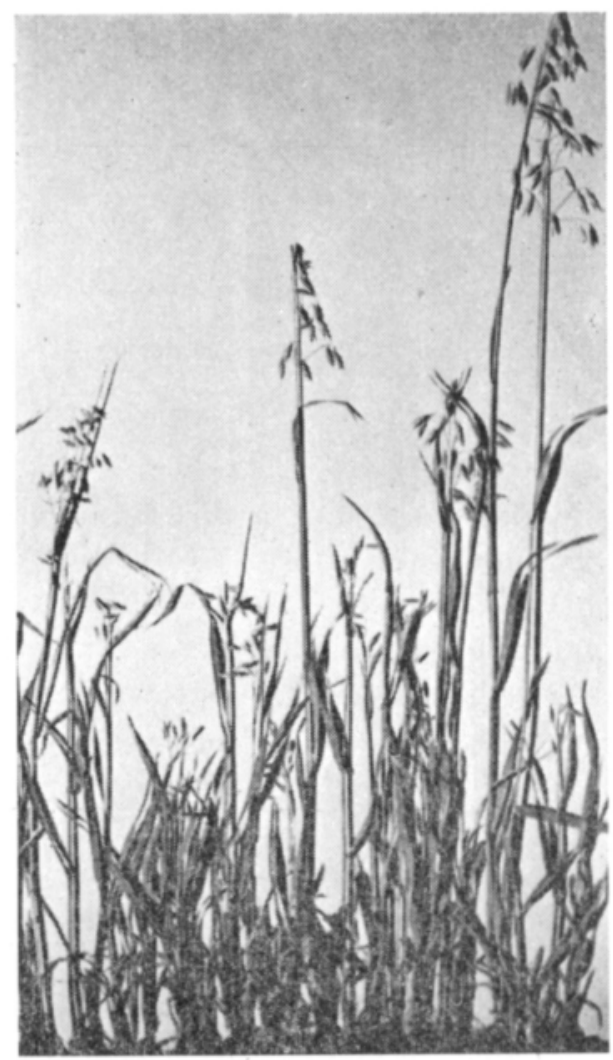

Kuva 1. Viljakaskaan vioittamaa kauraa elokuun puolivälin tienoilla 1956 (10)

Fig. 1. Oats damaged by Calligypona pellucida about the middle of August in $1956(10)$.

puolikulttuuriniityillä sekä soilla. Selvästi runsaimpana se on ainakin kyseessä olevalla rannikkoalueella viljapelloissa ja niihin kylvetyissä heinänurmissa seuraavana keväänä. Viljapellot ovat sen pääasiallisia lisääntymisbiotooppeja ja niihin kylvetty timotei kuoriutuvien toukkien tärkeä ravintokasvi. Toukka-aikana viljakaskaan liikkuminen on verraten rajoitettua. Vasta aikuistuttuaan munintaa seuraavan vuoden kesäkuussa se lentotaitoisena hyönteisenä saavuttaa verraten hyvän liikkumiskyvyn. Tällöin se hakeutuu kesäkuun alun — heinäkuun puolivälin aikana tyynillä, lämpimillä säillä viljamaihin, joissa se aiheuttaa imennällään kauran, vehnän ja ohrankin tuhoutumista ( 8 ja 9$)$. 
Ensimmäiset tiedot kaurantuhon merkittävästä esiintymisestä länsirannikolla ovat vuodelta 1948, jolloin BERGER (1) mainitsee sitä havaitun Vaasan lähettyvillä, luultavasti ensinnä Koivulahdella. Syksyllä 1956 lähetettiin silloisen tuhoalueen ja sen lähiympäristön viljelijöille kirjeellinen kysely, jossa tiedusteltiin mm. tuhon havaitsemisvuotta viljelmällä. Kuvassa 2 on kysymykseen saatujen vas-

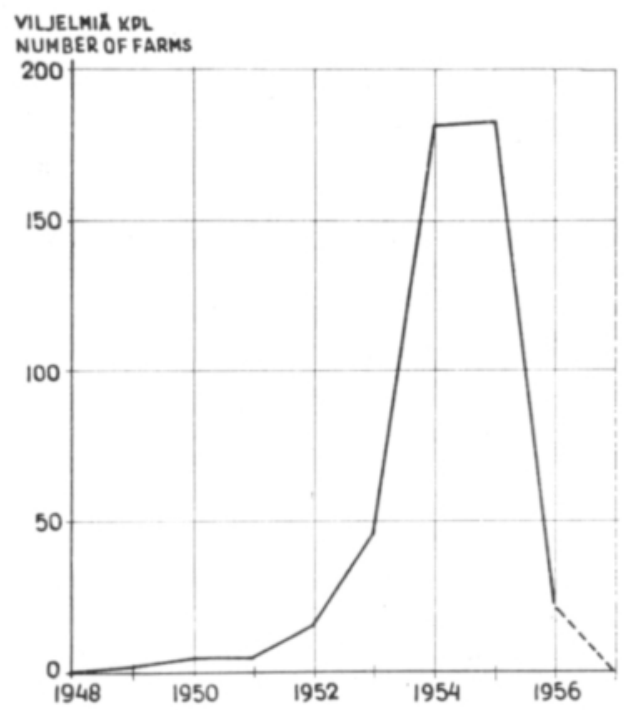

Kuva 2. Kaurantuhon vuosittain saastuttamien viljelmien lukumäärä v. 1956 suoritetun kyselyn perusteella. Vuoden 1957 tieto perustuu kirjoittajien arviointiin.

Fig. 2. The numbers of the farms annually injured by the damage to oats according to the inguiry in 1956.

The numbers in 1957 based on the evaluation of the authors.

tausten tulokset $(574 \mathrm{kpl})$ ryhmitettyinä vuosittain. Siitä ja kuvasta 3 käy ilmi tuhoalueen voimakas laajeneminen vuoteen 1954 saakka, mikä saattaa johtua esimerkiksi tuhoa levittävien kaskaiden leviämisestä, kaskaskannassa ilmeisesti tapahtuneesta massaesiintymisestä, tuhoon vaikuttavista toistaiseksi heikosti tunnetuista ulkoisista (sää tms.) tekijöistä ja näiden yhteisvaikutuksesta.

Vuosien $1954-55$ huipun jälkeen vain 22 viljelijää ilmoitti tuhon ilmaantuneen ensi kerran vuonna 1956 viljelyksilleen. Tämä saattaa johtua osittain vastausten pienestä lukumäärästä, niiden epätasaisesta jakautumisesta ja mainittuna vuonna esiintyneistä hallatuhoista, jotka vaikeuttivat kaurantuhon toteamista. Vuosina 1957 ja 1958 ei kuitenkaan enää todettu uusia tuhotapauksia ja tuho oli niin lievää, että vain aniharva viljelijä edes tuhoalueella totesi sen esiintymisen.

Tuhoalueen laajentumisessa on täten aineiston mukaan tapahtunut vuodesta 1955 alkaen hidastumista.

Kartasta (kuva 4) nähdään v. 1956 suoritetun kenttätutkimuksen perusteella tuhon levinneisyys ja arvioitu voimakkuus kyseisenä vuonna. Siitä ilmenee, että tuho on ollut voimakkainta Kokkolan ja Siipyyn välisellä rannikkoalueella (lähes 


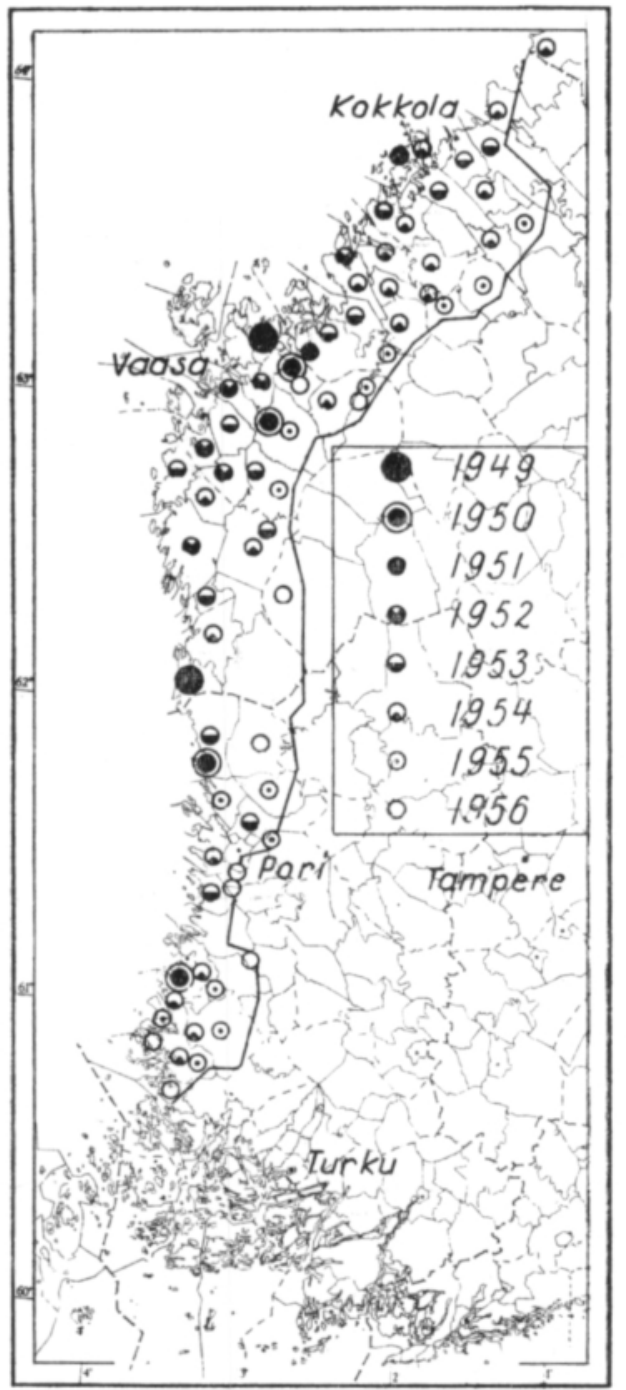

Kuva 3. Kaurantuhon ilmaantuminen eri alueille viljelijöiden antamien tietojen mukaan (10). Fig. 3. The appearance of the damage to oats in different tracts according to information given by farmers (10).

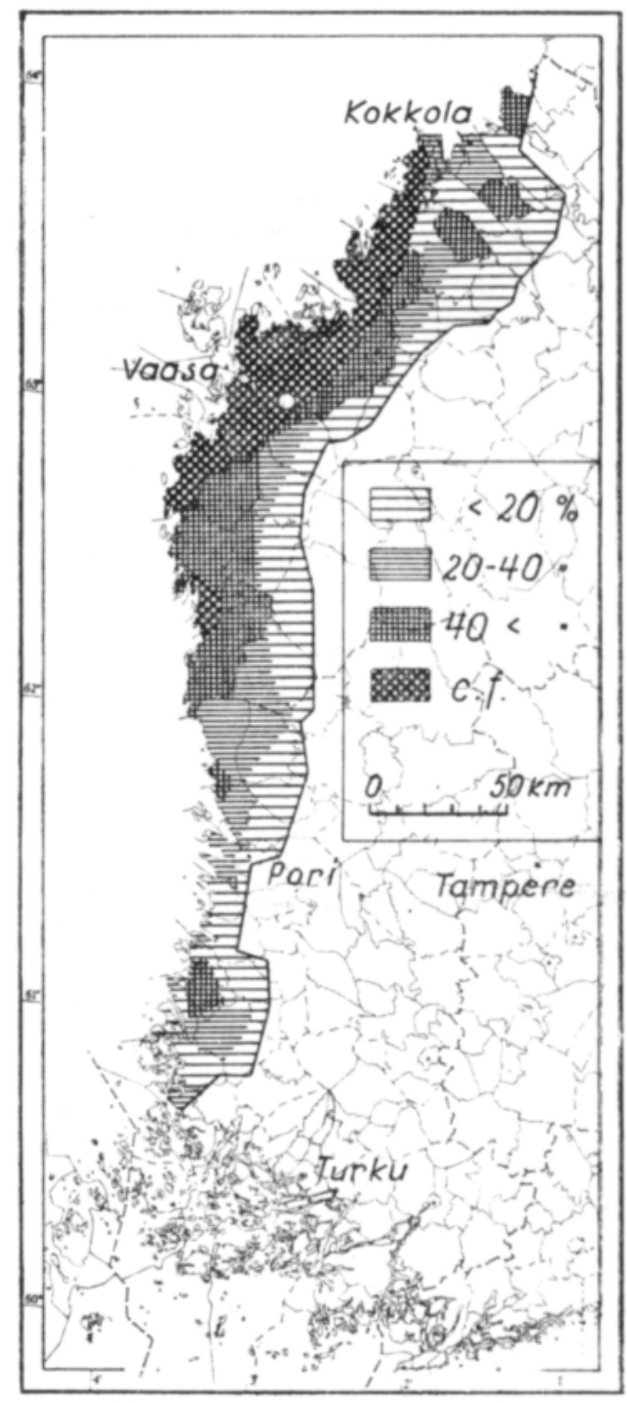

Kuva 4. Kaurantuhon levinneisyys ja arvioitu voimakkuus v. 1956 tuhoeläintutkimuslaitoksen havaintojen mukaan. c.f. = viljely käytännöllisesti katsoen lopetettu (10).

Fig. 4. The distribution area and evaluated intensity of damage in 1956 according to the observations made by Dept. of Pest Investigation. c.f. = oat cultivation practically given up (10).

koko Österbottens svenska lantbrukssällskap'in alueella vrt. kuvaan 5). Tältä alueelta sisämaahan päin siirryttäessä tuho on heikennyt nopeasti omaten verraten leveän lievän tuhoutumisasteen reunavyöhykkeen, jolla tuho on ilmennyt saarekkeittain.

Tuhoalue rajoittuu pohjoisosassaan vähäpeltoiseen Kalajoen nummialueeseen ja eteläosassaan Lokalahdella, epäselvästi Lounais-Suomen tärkeään maanviljelys- 
alueeseen. Leveydeltään vyöhyke on mantereella noin $10-60 \mathrm{~km}$. Kapein kohta sijaitsee Kokemäenjoen eteläpuoleisella karulla hiekkakivialueella ja levein Eteläja Keski-Pohjanmaan viljan- ja heinänviljelyalueilla. Suomenselällä ja edellä mainituilla karuilla alueilla tuho esiintyi joko keskimäärin lievänä tai se rajoittui suorastaan niihin, mikä saattaa johtua esim. kyseessä olevien alueiden viljelysten vähäisyydestä ja hajallisesta esiintymisestä, jotka muodostavat kaskaskannalle leviämisesteitä, tai muulla tavoin vaikuttavat kannan runsauteen ja sen levittämän tuhon ilmenemiseen.

\section{Tuhon voimakkuuserot}

Tuhon ankaruudessa on melkoisia vaihteluja sekä samana vuonna läheisillä viljelyksillä että eri vuosina samalla viljelyksellä, samoin kuin koko tuhoalueellakin. Syinä tällaisiin vaihteluihin ovat mm. tekijät, jotka säätelevät tuhoa aiheuttavan kaskaskannan lukumäärää. Viljakaskaskannan suurentuminen vaikuttaa tuhoa lisäävästi, pienentyminen päinvastoin.

Teoreettisesti on pääteltävissä: 1) Mitä enemmän on viljamaita sitä enemmän viljakaskailla on suotuisia lisääntymispaikkoja. Muissa biotoopeissa viljakaskaat lisääntyvät yleensä melko vähän. 2) Mitä enemmän on viljakasveihin perustettu heinänurmia, sitä paremmat mahdollisuudet lisääntyneellä kaskaskannalla on aikuistua. Sen sijaan ravintokasvittomissa sänkipelloissa tuhoutuu suurin osa toukista.

Edellisestä seuraa, että mitä suuremmaksi viljakasveihin kylvettyjen 1.-vuoden heinänurmien pinta-alan suhde viljakasvien viljelyalaan (suhde $=\mathrm{H}$ ) muodostuu sitä enemmän on odotettavissa aikuistuvia viljakaskaita viljakasvialaan verrattuna ja sitä voimakkaampaa pitäisi tuhon olla. Vanhat nurmet, piennarkasvus-

Taulukko 1. Tuhoalueen ja sen läheisten maanviljelysseurojen 1,-vuoden peltonurmien ja viljakasvien viljelyala sekä suhde $\mathrm{H}$ yli 2 ha peltoa käsittävillä viljelmillä maatalouslaskennan mukaan v. 1950 Table 1. The acreages of the 1st year seeded grasslands and cereals at the area of damage and of some agricultural societies. The ratio $H$ (see text) in the farms with 2 or more hectare of arable land according to the Annual Statistics of Agriculture in 1950.

\begin{tabular}{|c|c|c|c|}
\hline $\begin{array}{l}\text { Maanviljelysseura } \\
\text { Agricultural society }\end{array}$ & $\begin{array}{l}\text { 1.-vuoden pelto- } \\
\text { nurmien ala ha } \\
\text { Acreages of the } \\
\text { 1st year seeded } \\
\text { grasslands ha }\end{array}$ & $\begin{array}{l}\text { Viljakasvien } \\
\text { viljelyala ha } \\
\text { Acreages of } \\
\text { the cereal } \\
\text { crops ha }\end{array}$ & $\begin{array}{c}\text { H-suhde } \\
\text { Ratio } H\end{array}$ \\
\hline Österbottens svenska lbs (1) & 19603 & 34685 & 0.57 \\
\hline Keski-Pohjanmaan mvs (2) & 10760 & 22855 & 0.47 \\
\hline Etelä-Pohjanmaan mvs (3) & 36306 & 84210 & 0.43 \\
\hline Keski-Suomen mvs $(6)$ & 13428 & 33760 & 0.40 \\
\hline Satakunnan mvs (4) & 24169 & 86152 & 0.28 \\
\hline Hämeen-Satakunnan mvs ( $(7)$ & 9740 & 35233 & 0.28 \\
\hline Hämeen läänin mvs ( 8$)$ & 16607 & 64031 & 0.26 \\
\hline Varsinais-Suomen mvs $(5)$ & 24857 & 100693 & 0.25 \\
\hline Koko maa Whole country & 292749 & 850786 & 0.34 \\
\hline
\end{tabular}


tot ja peltojen laiteet saattavat olla eräissä tapauksissa merkittäviä viljakaskaan lisääntymispäikkoja, jotka tulee myös ottaa huomioon suhteen $\mathrm{H}$ perusteella päätelmiä tehdessä. 1.-vuoden ja vanhempien heinänurmien alat ovat jokseenkin samassa suhteessa toisiinsa koko alueella (n. 1:3.2), joten ne vaikuttavat molemmat samaan suuntaan.

Taulukossa 1 esitetään tuhoalueen ja sen läheisten maanviljelysseurojen alueilta vuodelta 1950 lasketut $\mathrm{H}: \mathrm{n}$ arvot. Peltonurmien suojakasvia tai sen puuttumista ei ole voitu ottaa huomioon laskussa; VAllen ja PAATElAn (15) mukaan

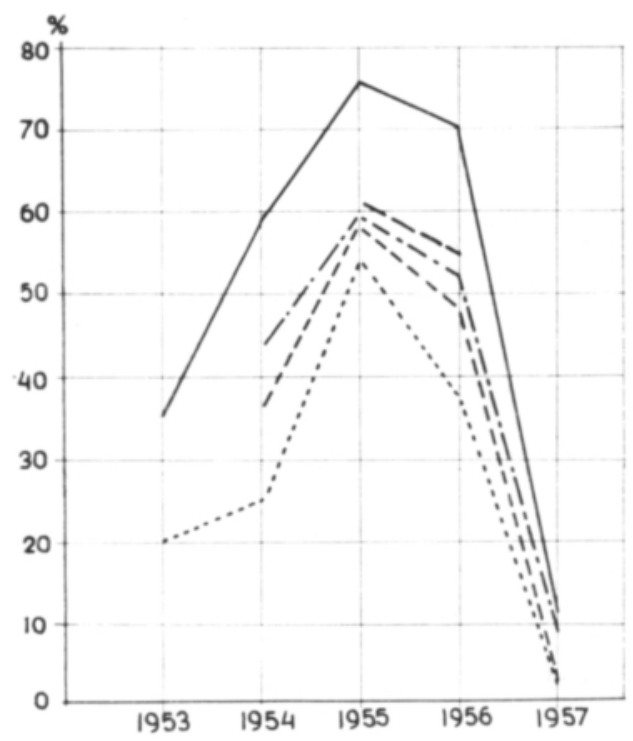

Kuva 5. Kaurantuhon voimakkuus eräillä tiloilla maanviljelysseuroittain. Vuosien 1953 -56 tiedot ovat viljelijöiden antamien tietojen keskiarvoja ja vuoden 1957 tiedot perustuvat tekijäin havaintoihin, jotka on mukautettu edellisiin verrattaviksi. $-=$ Ósterbottens svenska lbs $(1)$, $--=$ KeskiPohjanmaan mvs $(2),-\cdot--=$ Etelä-Pohjanmaan mvs $(3),---=$ Satakunnan mvs $(4), \ldots=$ Varsinais-Suomen mvs (5).

Fig. 5. The severity of damage in the farms evaluated by the agricultural societies. The numbers in $1953-56$ are the means of information given by farmers and the numbers in 1957 are based on the observations of the authors accommodated to be comparable with the numbers mentioned above. Agricultural societies mentioned in the finnish text above.

perustettiin koko maassa peltonurmista $42 \%$ kauraan, $21 \%$ ohraan, $19 \%$ kevätvehnään, $11 \%$ syysrukiiseen, $2 \%$ syysvehnään, $3 \%$ vihantarehuun ja vain $2 \%$ kesantoon. Taulukosta käy ilmi, että suurin $\mathrm{H}: \mathrm{n}$ arvo on Österbottens svenska lantbrukssällskap'in alueella ja pienin Varsinais-Suomen maanviljelysseuran alueella. Edellisen seuran alueella on taulukon perusteella viljakasveihin kylvetyissä heinänurmissa aikuistuva kaskaskanta (teoreettisesti) levittäytynyt noin kaksi kertaa laajemmalle alalle kuin millä se on aikuistunut, jälkimmäisellä alueella taas noin neljä kertaa laajemmalle alueelle. Viime mainitulla alueella pitäisi täten kaskastiheyden olla selvästi pienempi kuin edellisellä. Syksyllä 1956 tehdyt toukkien laskentahavainnot osoittavat tilanteen olevan tämän suuntaisen. Samoin Vaasan seudussa vv. 1956 ja 1957 suoritetut tutkimukset viljakaskaan munamääristä 
tuhoalueen laajentumisen hidastumisen ja tuhon lievenemisen sisämaahan siirryttäessä.

Mistä johtuu vuoden 1957 hyvä kaurasato edelliseen vuoteen verrattuna? Yhtenä syynä siihen on ilmeisesti viljakaskasmäärässä tapahtunut kannan väheneminen. Keväällä 1956 todettiin imunäyttein $\left(3 \times 0.10 \mathrm{~m}^{2}\right) 11$ kevätviljaan kylvetyssä 1.-vuoden timoteimaassa keskimäärin 927 viljakaskastoukkaa $/ \mathrm{m}^{2}$, keväällä 1957 niitä oli vain $163 / \mathrm{m}^{2} 13$ havaintopaikan keskiarvona. Tulokset osoittavat siis toukkamäärän pienentyneen n. 1/5 osaan. Munaryhmien (keskimäärin 10.9 munaa ryhmässään) määrässä 100 kasvia kohden havaittiin pienentymistä 42.5:stä 22.3:een 11 havaintomaassa. Samansuuntainen kaskaskannan lasku on todettu Ruotsissakin (12 ja SömermaA suullisesti). Syynä tällaiseen laskuun voivat olla kesän 1956 sekä seuraavan talven ja kevätkesän bioottiset ja abioottiset tekijät, mm. talven lumettomuus ja tulvat.

Toisena syynä tähän on viljakaskaiden kesällä 1957 myöhäisemmät parveiluajat kauran kehitysasteeseen nähden edelliseen vuoteen verrattuna. Tästä johtuen ne eivät päässeet vioittamaan kasveja yhtä aikaisin ja riittävän suurin määrin, jotta tuho olisi ilmennyt ankarana. Kolmanneksi tuhon ankaruuteen ilmeisesti vaikuttavat jotkin toistaiseksi heikosti tunnetut (esim. kosteus ja lämpö) ja tuntemattomat tekijät, joiden erilaisuus saattoi aiheuttaa osaltaan v:n 1957 lievemmän tuhon kuin edellisenä vuonna.

\section{Kauran sadot ja vilielyalat tuhoalueella ja sen läheisyydessä}

Viljakaskaan aiheuttaman kaurantuhon voimakkuudesta, yleistymisestä sekä sen viljelykasvialoihin aiheuttamista muutoksista saa tilastollista todistusaineistoa maataloustilastosta (16) sekä kirjanpitotilojen vuosikatsauksista.

Kuten kuvista 4 ja 7 ilmenee, käsitti kaurantuhoalue 1956 koko Österbottens svenska lantbrukssällskap'in alueen sekä lisäksi osia Keski-Pohjanmaan, EteläPohjanmaan, Satakunnan ja Varsinais-Suomen maanviljelysseurojen alueista. Maataloushallituksen vuosittain laatimasta maataloustilastosta saatuja sato- ja viljelyalatietoja vertaamalla voidaan nähdä kaurantuhon voimakkuus ja vaikutus erittäin selvästi ensiksi mainitun mv-seuran alueella ja samansuuntaisena myös muiden seurojen alueella. Vertailun vuoksi on mukaan otettu myös KeskiSuomen ja Hämeen-Satakunnan maanviljelysseurojen alueet sekä koko maan satoa ja viljelyalaa koskevat tiedot.

Maanviljelysseuroittain laaditusta diagrammista (kuva 6) käy selville kauran hehtaarisatojen vaihtelu vuosina 1950 - 1957. Vuosien 1950 ja 1951 sadot olivat lähes normaaleja, kasvukausi 1952 oli loppupuolesta erittäin sateinen, joten huonot sadot Pohjanmaalla, erikoisesti tulvanaralla Keski-Pohjanmaalla johtuvat pääosaltaan sadevaurioista eikä tuhon vaikutus vielä ole näkyvissä. Vuoden 1953 kaurasato oli koko maassa varsin runsas ollen kolmen ensiksi mainitun mv-seuran alueella n. $1700 \mathrm{~kg} /$ ha ja vajaa $200 \mathrm{~kg}$ alle koko maan keskisadon eikä kaurantuhon vaikutus vielä tilastollisesti selvästi näy (vrt. kuva 5). 1954 oli Österbottens svenska lantbrukssällskap'in alueen kaurasato jo n. $600 \mathrm{~kg} / \mathrm{ha}$, v. $1955 \mathrm{n} .800 \mathrm{~kg} / \mathrm{ha}$ 


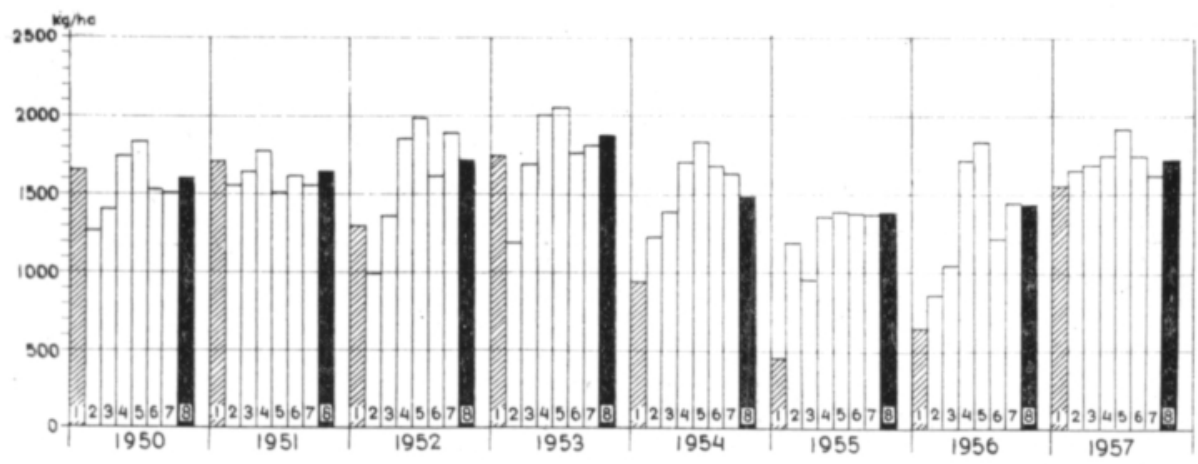

Kuva 6. Kauran hehtaarisadot eräiden maanviljelysseurojen alueilla vuosina $1950 \_57$ Maataloustilaston mukaan. 1 = Österbottens svenska lbs, $2=$ Keski-Pohjanmaan mvs, $3=$ Etelä-Pohjanmaan mvs, $4=$ Satakunnan mvs, $5=$ Varsinais-Suomen mvs, $6=$ Keski-Suomen mvs, $\gamma=$ Hämeen-Satakunnan mvs, $8=$ Koko maa Whole country

Fig. 6. The hectare yields of oats in the areas of some agricultural societies according to the Annual Statistics of Agriculture in 1950-57. Agricultural societies mentioned in the finnish text above.

ja $1956 \mathrm{n} .700 \mathrm{~kg} /$ ha pienempi kuin koko maan keskisato. Pohjanmaan muiden mvseurojen sadot olivat myös pienentyneet, vaikka eivät aivan yhtä voimakkaasti, sillä kuuluihan näiden mv-seurojen alueista vain osa tämän tuhon vaikutuksen alaisuuteen. Vuoden 1957 sadot ovat taas verrattain hyvät eikä suuria poikkeamia tuhoalueen ja sen ulkopuolisten mv-seurojen välillä ole havaittavissa.

Taulukko 3 antaa kuvan eri vuosien hehtaarisadon poikkeavuudesta vuosien 1946 - 53 keskisadosta. On syytä huomata, että huono sato v. 1955 Satakunnan, Hämeen-Satakunnan ja Varsinais-Suomen mv-seurojen alueella johtuu pääosaltaan ankarasta kuivuudesta. V. 1956 sadon pienuuteen Pohjanmaan ja Keski-Suomen alueilla ovat vaikuttaneet melkoisesti myös hallavauriot. Edellä esitettyinä vuosina ei tuhoeläintutkimuslaitoksen tietojen mukaan ole läntisellä rannikkoalueella esiintynyt kahukärpästä eikä muitakaan tuholaisia tai kasvitauteja erityisen runsaana, joten heikot sadot kolmen ensinmainitun maanviljelysseuran alueella joh-

Taulukko 3. Kauran vuosisadon poikkeavuus kg/ha kunkin maanviljelysseuran 8-vuotiskauden 1946-53 keskisadosta.

Table 3. The deviations $\mathrm{kg} / \mathrm{ha}$ of the annual yields of oats from the mean yields (in the period of eight years $1946-53)$ by agricultural societies.

\section{Maanviljelysseura}

Agricultural society

$\begin{array}{llllllll}1950 & 1951 & 1952 & 1953 & 1954 & 1955 & 1956 & 1957\end{array}$

\begin{tabular}{|c|c|c|c|c|c|c|c|c|}
\hline Österbottens svenska lbs (I) & +134 & +275 & -229 & +223 & -594 & -1059 & -874 & 26 \\
\hline Keski-Pohjanmaan mvs (2) & +70 & +364 & -221 & +498 & +34 & -7 & -336 & 6 \\
\hline Etelä-Pohjanmaan mvs (3) & +9 & +262 & -68 & +295 & + & -439 & -346 & \\
\hline Satakunnan mvs (4) & +105 & +127 & +206 & +358 & +57 & -289 & +69 & \\
\hline Varsinais-Suomen mvs $(5)$ & +178 & -155 & +333 & +411 & +176 & -378 & +165 & \\
\hline Keski-Suomen mvs $(6)$ & +101 & +206 & +199 & +301 & +265 & -46 & -200 & \\
\hline Hämeen-Satakunnan mvs (7) & -129 & -73 & +259 & +170 & -8 & -271 & -168 & \\
\hline Koko maa Whole country & +64 & +97 & +168 & +346 & +47 & -163 & -122 & +1 \\
\hline
\end{tabular}


tuvat joko epäedullisista sääoloista (1952) tai viljakaskaan aiheuttamasta tuhosta (1955) tai molempien yhteisvaikutuksesta (1954 ja 1956).

Paitsi määrällisesti huonontaa viljakaskas myös laadullisesti kauran satoa. Niinpä tuhoeläintutkimuslaitoksen torjuntakokeissa 1956 todettiin käsiteltyjen kauramaiden (tuho lievää) sato keskimäärin hehtolitrapainoltaan $4 \mathrm{~kg}$ suurem-

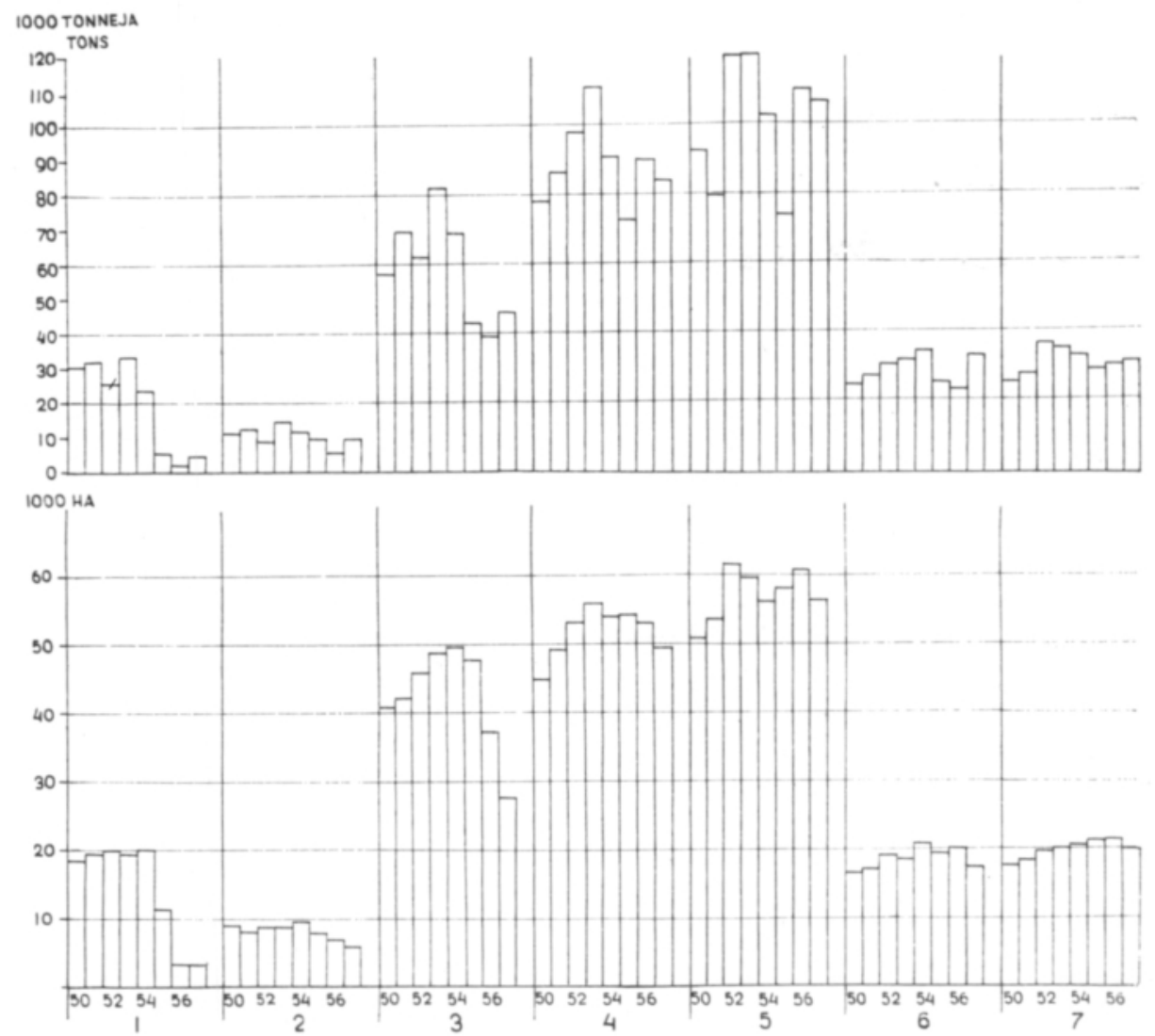

Kuva 7. Kauran viljelyala 1000 ha:ja ja kokonaissato 1000 tonneja vuosina $1950-57$ Maataloustilaston mukaan. Alueiden numerot kuten kuvassa 6.

Fig. 7. Acreages and the total yields of oats according to the Annual Statistics of Agriculture in $1950-57$. The agricultural societies marked as in fig. 6.

maksi ja kahuprosentti $6 \%$ pienemmäksi kuin vastaavien käsittelemättömien, melko pahoinkin tuhoutuneiden maiden sato.

Viljakaskaan aiheuttamista huonoista sadoista on välittömästi ollut seurauksena kauran viljelyalan pieneneminen (kuva 7). Österbottens svenska lbs:n alueella oli kaura-ala $1955 \mathrm{n}$. puolet edellisen vuoden alasta, 1956 ja 1957 vain 1/6 v. 1954 alasta. Saman suuntaiset muutokset on havaittavissa myös Keski- ja Etelä-Pohjanmaan mv-seurojen alueella, joskaan ei yhtä selvinä. Muiden mv-seurojen alueilla sekä koko maan kauranviljelyaloissa on havaittavissa vain hyvin vähäistä pienenemistä vastaavana aikana. 
Taulukko 4. Kaurantuhon vaikutus kauran kokonaissatoon Österbottens svenska lbs:n alueella.

Table 4. The effect of damage to oats on the total yield of oats at the area of agricultural society 1 (see fig. 8 )

\begin{tabular}{|c|c|c|c|}
\hline $\begin{array}{l}\text { Vuosi } \\
\text { Year }\end{array}$ & $\begin{array}{l}\text { Kunakin vuonna } \\
\text { saatu sato tonnia } \\
\text { Annwal yield } \\
\text { tons }\end{array}$ & $\begin{array}{l}\text { Keskisadon perus- } \\
\text { teella laskettu sato tonnia } \\
\text { The theorethical yield } \\
\text { in tons, counted on the } \\
\text { basis of the mean yield }\end{array}$ & $\begin{array}{l}\text { Erotus } \\
\text { tonnia } \\
\text { Difference } \\
\text { tons }\end{array}$ \\
\hline 1950 & 30243 & 27747 & +2496 \\
\hline 1951 & 32813 & 29442 & +3371 \\
\hline 1952 & 25721 & 30256 & -4535 \\
\hline 1953 & 33666 & 29379 & +4287 \\
\hline 1954 & 18623 & 30467 & -11844 \\
\hline 1955 & 5284 & 17216 & -11932 \\
\hline 1956 & 2005 & 4683 & -2678 \\
\hline 1957 & 4734 & 4654 & +80 \\
\hline
\end{tabular}

Jos arvioidaan kaurantuhon Österbottens svenska lbs:n alueen viljelijöille aiheuttamia satotappioita, saadaan summittainen kuva kertomalla vuosittainen kauranviljelypinta-ala esim. 8-vuotiskauden 1946-1953 keskihehtaarisadolla ja vähentämällä tästä luvusta ko. vuonna saatu sato. Taulukosta 4 ilmenevät nämä erotukset.

Kolmen vuoden $1954-56$ aikana on täten laskettu satotappio yhteensä n. 26000 tonnia kauraa ja $25 \mathrm{mk}$ :n kilohinnan mukaisesti yli n. 650 milj. markkaa. Etelä-Pohjanmaan mv-seuran toimialueen useissa kunnissa on myös suoritettu tuhoarviointeja. Niinpä v. 1955 Laihialla 154:llä arviointia pyytäneellä tilalla (yhteispeltoalaltaan 2133 ha) oli 444 ha kaura-ala tuhoutunut keskim. $83 \%$ :sti. Havainnollisen kuvan tuhon taloudellisesta merkityksestä antavat myös kauransiemenen kauppaa harjoittavan Vähänkyrön Osuuskaupan oheisesta taulukosta (taulukko 5a) ilmenevät kauranvälitysmäärät (johtaja P. Suvanto suullisesti).

Taulukko 5a. Vähänkyrön Osuuskaupan toimialueeltaan ostaman kauran määrä sekä raha-arvo vuosina $1950-1957$.

Table 5a. The amount and sale value of oats bought by a cooperative store at Vähäkyrö (Vähänkyrön Osuuskauppa) from its area of sale.

\begin{tabular}{ccccc}
\hline $\begin{array}{c}\text { Vuosi } \\
\text { Year }\end{array}$ & $\begin{array}{c}\text { Siemenkauraa } \\
\text { tonnia } \\
\text { Seed oats tons }\end{array}$ & $\begin{array}{c}\text { Rehukauraa } \\
\text { tonnia } \\
\text { Fodider oats tons }\end{array}$ & $\begin{array}{c}\text { Yhteensä } \\
\text { tonnia } \\
\text { Total tons }\end{array}$ & $\begin{array}{c}\text { Raha-arvo } \\
\text { milj. markkaa } \\
\text { Sale value mill. mks. }\end{array}$ \\
\hline 1950 & 400 & 687 & 1087 & 19.3 \\
1951 & & & 932 & 23.2 \\
1952 & 472 & & 1129 & 27.4 \\
1953 & 184 & 890 & 1362 & 27.6 \\
1954 & 8 & 572 & 580 & 1054 \\
1955 & 24 & 267 & 291 & 7.2 \\
1956 & 10 & 85 & 95 & 2.4 \\
\hline
\end{tabular}


Käsityksen siitä, millainen on pellon käyttö kaurantuhon vaivaamilla alueilla ja minkä kasvin viljelyyn kaurasta luopumisen jälkeen on siirrytty, antavat Maataloushallituksesta saadut ns. kirjanpitotilojen tilastotiedot. Tilat on jaoiteltu viiteen ryhmään sijaintinsa mukaan tuhon eri voimakkuusalueilla (vrt. kuva 4)

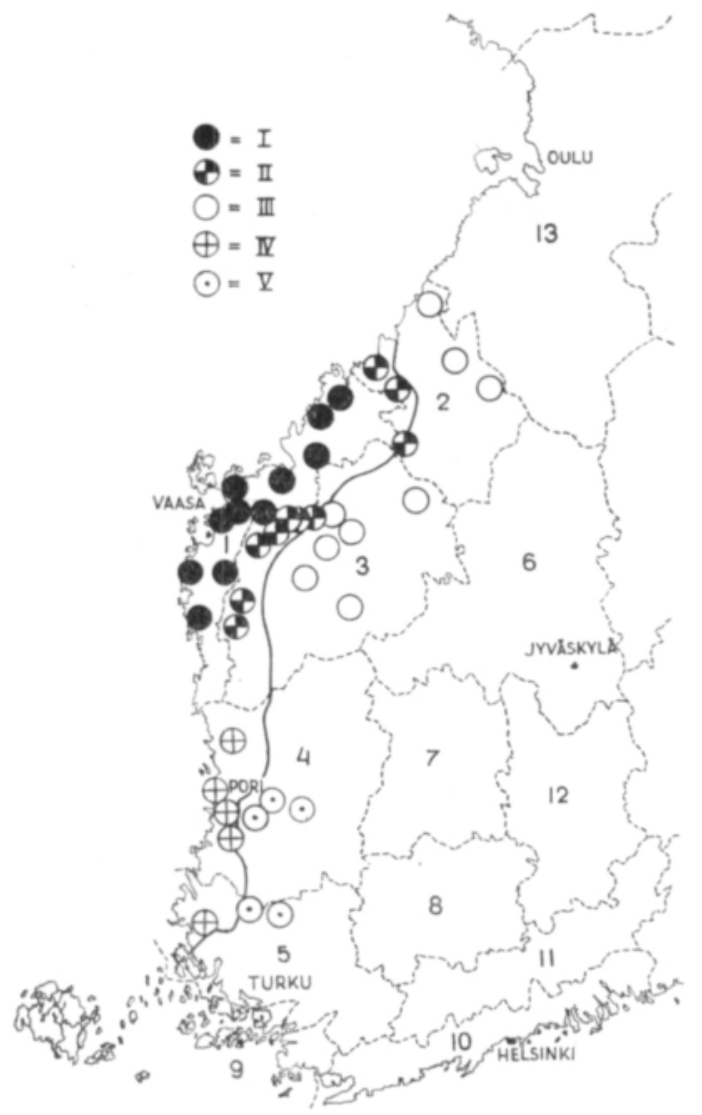

Kuva 8. Tutkimuksessa käytettyjen kirjanpitotilojen sijainti sekä maanviljelysseurojen ja kaurantuhoalueen rajat v. 1956. Kirjanpitotilojen ryhmät: $\mathrm{I}=$ Ruotsalaisen tuhoalueen, $\mathrm{II}=$ Pohjanmaan tuhoalueen, III $=$ Pohjanmaan vertailualueen, IV $=$ Satakunnan tuhoalueen ja $\mathrm{V}=$ Satakunnan vertailualueen kirjanpitotilat. Maanviljelysseurat: Numerot $1-7$ kuten kuvassa $6,8=$ Hämeen läänin mvs, $9=$ Finska hushăllningssällskap, $10=$ Nylands svenska lbs, $11=$ Uudenmaan läänin mvs, $12=$ Itä-Hämeen mvs, $13=$ Oulun läänin talousseura.

Fig 8. The location of the book-keeping farms used in this study and the boundary lines of the agricultural societies and those of the damage to oats in 1956. The croups of book-keeping farms and agricultural societies mentioned in finnish text above

ja useimmilta on satotiedot yhtäjaksoisesti vuosilta $1950-56$. Tilojen ryhmitys ja sijaintikunta ilmenee kuvasta 8. Ruotsalaisen tuhoalueen (I) tilat yhteensä 11 (1950 10) ovat pinta-alaltaan 5-32 ha (tilojen joukkoon otettu viljelysolosuhteiltaan vastaava Vähänkyrön kuntaan kuuluva tila), Pohjanmaan tuhoalueen (II) 10 tilaa (1959 9) 10—50 ha ja Pohjanmaan vertailualueen (III), jossa tuhoa ei ole 
Taulukko 5 b. Kauran hehtaarisadot eräillä kirjanpitotiloilla.

Table 5 b. The yields of oats per hectare in some book-keeping farms.

,Kirjanpitotilojen ryhmät

The croups of book-keeping farms

1950

$1951 \quad 1952$

1953

$1954 \quad 1955 \quad 1956$

\begin{tabular}{lrrrrrrr}
\hline Ruotsalainen tuhoalue $(I)$ & 1968 & 1907 & 1964 & 1707 & 463 & 593 & - \\
Pohjanmaan vertailualue $(I I I)$ & 2052 & 1876 & 1512 & 1760 & 1288 & 1529 & 1079 \\
\hline Erotus Difference & -84 & +31 & +452 & -53 & -824 & -936 & - \\
& & & & & & & \\
Satakunnan tuhoalue $(I V)$ & 2355 & 1947 & 2424 & 2367 & 1776 & 880 & 1296 \\
Satakunnan vertailualue $(V)$ & 2864 & 2742 & 3054 & 2652 & 1953 & 2256 & 2887 \\
\hline Erotus Difference & -509 & -795 & -630 & -285 & -177 & -1376 & -1591
\end{tabular}

Taulukko 6. Ruotsalaisen tuhoalueen (I) kirjanpitotilojen pellon käyttö \%

Table 6. The percentage of the use of cereals in the book-keeping farms of the area $I$.

\begin{tabular}{|c|c|c|c|c|c|c|c|}
\hline & 1950 & 1951 & 1952 & 1953 & 1954 & 1955 & 1956 \\
\hline Syysviljat Winter cereals & 2.9 & 2.7 & 2.8 & 1.1 & 1.1 & 1.8 & 3.1 \\
\hline Kevätvehnä Spring wheat & 7.6 & 5.3 & 3.4 & 2.3 & 3.0 & 3.2 & 4.2 \\
\hline Ohra Barley & 5.3 & 3.6 & 4.8 & 8.0 & 6.3 & 9.7 & 14.1 \\
\hline Kaura Oats & 16.0 & 17.1 & 18.3 & 18.1 & 17.5 & 6.9 & 一 \\
\hline Seosvilja Mixed cereal & 2.2 & 0.6 & - & 1.9 & 5.8 & 5.3 & 3.2 \\
\hline Syysrypsi Winter turnip rape & $e$ - & 0.2 & 0.8 & 0.6 & 0.9 & 1.2 & 1.3 \\
\hline $\begin{array}{l}\text { Peruna ja juurik. Potatoes } \\
\text { and beets }\end{array}$ & 4.1 & 4.5 & 4.1 & 3.2 & 4.2 & 4.9 & 4.8 \\
\hline Nurmet Hay plants & 60.9 & 64.4 & 64.2 & 63.2 & 57.7 & 62.5 & 65.6 \\
\hline Muut kasvit Other plants & 0.6 & 0.5 & 0.6 & 0.3 & 0.5 & 0.9 & 0.2 \\
\hline Kesanto Bare fallow & 0.4 & 1.1 & 1.0 & 1.3 & 3.0 & 3.6 & 3.5 \\
\hline & 100 & 100 & 100 & 100 & 100 & 100 & 100 \\
\hline $\begin{array}{l}\text { Koko peltoala ha } \\
\text { Total arable land ha }\end{array}$ & 179 & 189 & 185 & 198 & 188 & 195 & 158 \\
\hline
\end{tabular}

esiintynyt, 9 tilaa $10-52$ ha. Viimeksi mainitun alueen tiloista useimmat ovat sateisina vuosina kärsineet tulvista, jotka ovat alentaneet viljasatoja. Satakunnan tuhoalueen (V) 5 (1956 4) tilat ovat $7-48$ ha:n suuruisia vastaavan vertailualueen tilojen (V) 6 (1956 5) ollessa samaa suuruusluokkaa.

Näin ryhmiteltyjen kirjanpitotilojen kaurasatojen määrät (taulukko 5 b) antavat samanlaisen kuvan tuhon voimakkuudesta kuin maanviljelysseurojenkin tilastot.

Peltoalan käytössä poikkeavat alueet toisistaan. Kauran osuus oli II, IV ja V alueella $20-30 \%$ peltoalasta kun taas I ja III se oli n. $15 \%$ tienoilla. Oheiset taulukot 6-10 osoittavat kauran viljelyalan \%-osuuden peltoalasta eri vuosina. Tuhoalueiden kaura-alat ovat v:sta 1954 lähtien pienentyneet hyvin jyrkästi, jopa niin, että ruotsalaisella tuhoalueella viljely on v. 1956 kokonaan lopetettu. 
Taulukko 7. Pohjanmaan tuhoalueen (II) kirjanpitotilojen pellon käyttö \% Table 7. The percentage of the use of the cereals in the book-keeping farms of the area II.

\begin{tabular}{|c|c|c|c|c|c|c|c|}
\hline & 1950 & 1951 & 1952 & 1953 & 1954 & 1955 & 1956 \\
\hline Syysviljat Winter cereals & 4.0 & 5.4 & 3.7 & 2.3 & 2.9 & 4.5 & 9.0 \\
\hline Kevätvehnä Spring wheat & 6.8 & 6.5 & 3.2 & 2.1 & 6.8 & 5.0 & 7.3 \\
\hline Ohra Barley & 2.7 & 4.5 & 3.5 & 4.3 & 2.8 & 5.6 & 9.5 \\
\hline Kaura Oats & 22.6 & 19.8 & 27.2 & 28.1 & 21.8 & 20.0 & 8.2 \\
\hline Seosvilja Mixed cereal & 0.2 & 0.3 & 0.2 & 0.8 & 0.6 & - & 1.9 \\
\hline $\begin{array}{l}\text { Syysrypsi Winter turnip rap } \\
\text { Peruna ja juurik. Potatoes }\end{array}$ & e - & 0.2 & 0.2 & 2.6 & 1.4 & 2.4 & 2.4 \\
\hline and beets & 3.6 & 3.2 & 2.7 & 2.5 & 2.8 & 3.2 & 3.1 \\
\hline Nurmet Hav plants & 55.9 & 54.4 & 55.9 & 53.8 & 56.1 & 53.4 & 49.8 \\
\hline Muut kasvit Other plants & 1.2 & 1.3 & 0.6 & 0.2 & 0.1 & 0.2 & 0.5 \\
\hline Kesanto Bare fallow & 3.0 & 4.4 & 2.8 & 3.3 & 4.7 & 5.7 & 8.3 \\
\hline & 100 & 100 & 100 & 100 & 100 & 100 & 100 \\
\hline Koko peltoala ha & & & & & & & \\
\hline Total arable land ha & 251 & 254 & 258 & 263 & 262 & 275 & 228 \\
\hline
\end{tabular}

Taulukko 8. Pohjanmaan vertailualueen (III) kirjanpitotilojen pellon käyttö \%

Table 8. The percentage of the use of the cereals in the book-keeping farms of the area III.

\begin{tabular}{|c|c|c|c|c|c|c|c|}
\hline & 1950 & 1951 & 1952 & 1953 & 1954 & 1955 & 1956 \\
\hline Syysviljat Winter cereals & 5.4 & 5.4 & 5.1 & 3.1 & 3.8 & 4.3 & 5.3 \\
\hline Kevätvehnä Spring wheat & 4.4 & 4.3 & 2.5 & 2.8 & 3.2 & 3.9 & 4.5 \\
\hline Ohra Barley & 4.9 & 5.9 & 5.9 & 7.0 & 6.9 & 6.5 & 7.2 \\
\hline Kaura Oats & 11.7 & 13.5 & 15.8 & 18.6 & 16.0 & 14.2 & 13.6 \\
\hline Seosvilja Mixed cereal & 4.2 & 1.5 & 0.8 & 一 & - & - & 0.6 \\
\hline Syysrypsi Winter turnip rape & e - & 0.3 & - & 0.4 & 0.8 & 0.3 & 1.5 \\
\hline $\begin{array}{l}\text { Peruna ja juurik. Potatoes } \\
\text { and beets }\end{array}$ & 6.1 & 4.4 & 3.3 & 3.7 & 4.5 & 4.8 & 4.9 \\
\hline Nurmet Hay plants & 58.4 & 61.0 & 63.1 & 59.2 & 63.1 & 63.2 & 58.2 \\
\hline Muut kasvit Other plants & 0.7 & 0.4 & 0.7 & 0.6 & 0.3 & 0.1 & 0.1 \\
\hline Kesanto Bare fallow & 4.2 & 3.3 & 2.8 & 4.6 & 1.4 & 2.7 & 4.1 \\
\hline & 100 & 100 & 100 & 100 & 100 & 100 & 100 \\
\hline Koko peltoala ha & & & & & & & \\
\hline Total arable land ha & 223 & 230 & 232 & 232 & 232 & 232 & 232 \\
\hline
\end{tabular}

Taulukot 6-10 selventävät parhaiten eri viljakasvien osuutta peltopintaalasta sekä niitä keinoja, joita viljelijät ovat käyttäneet korvatakseen vähentyneen kaura-alan. Esim. ruotsalaisella tuhoalueella on vuosina 1954, 1955 ja 1956 yritetty seosviljan viljelyä, mutta koska kaura ei säilynyt seosviljassakaan on sen viljelyala vähenemässä. Tuhoalueella näyttää kaura korvatun ohralla ja nurmilla sekä jättämällä suurempi ala peltoa kesannoksi. 
Taulukko 9. Satakunnan tuhoalueen (IV) kirjanpitotilojen pellon käyttö \%

Table 9. The percentage of the use of the cereals in the book-keeping farms of the area IV.

\begin{tabular}{|c|c|c|c|c|c|c|c|}
\hline & 1950 & 1951 & 1952 & 1953 & 1954 & 1955 & 1956 \\
\hline Syysviljat Winter cereals & 3.5 & 3.1 & 3.2 & 3.8 & 4.7 & 4.6 & 6.1 \\
\hline Kevätvehnä Spring wheat & 10.5 & 7.0 & 5.8 & 4.4 & 5.4 & 6.1 & 6.7 \\
\hline Ohra Barley & 2.8 & 3.6 & 3.6 & 9.8 & 5.1 & 7.2 & 8.4 \\
\hline Kaura Oats & 25.4 & 28.8 & 29.7 & 21.0 & 24.9 & 22.2 & 19.1 \\
\hline Seosvilja Mixed cereal & 0.4 & 0.3 & - & - & - & - & 0.1 \\
\hline $\begin{array}{l}\text { Syysrypsi Winter turnip rape } \\
\text { Peruna ja juurik. Potatoes }\end{array}$ & $e-$ & 0.4 & 0.7 & 3.4 & 5.1 & 1.8 & - \\
\hline and beets & 7.4 & 6.5 & 6.8 & 6.0 & 7.5 & 7.2 & 5.0 \\
\hline Nurmet Hay plants & 49.4 & 48.9 & 49.1 & 45.4 & 46.4 & 47.3 & 48.1 \\
\hline Muut kasvit Other plants & 0.6 & 0.8 & 0.8 & 0.9 & 0.9 & 1.4 & 1.9 \\
\hline Kesanto Bare fallow & 一 & 0.6 & 0.3 & 5.3 & 一 & 2.2 & 4.6 \\
\hline & 100 & 100 & 100 & 100 & 100 & 100 & 100 \\
\hline $\begin{array}{l}\text { Koko peltoala ha } \\
\text { Total arable land ha }\end{array}$ & 147 & 150 & 148 & 149 & 151 & 161 & 113 \\
\hline
\end{tabular}

Taulukko 10. Satakunnan vertailualueen (V) kirjanpitotilojen pellon käyttö \%

Table 10. The percentage of the use of the cereals in the book-keeping farms of the area $V$.

\begin{tabular}{|c|c|c|c|c|c|c|c|}
\hline & 1950 & 1951 & 1952 & 1953 & 1954 & 1955 & 1956 \\
\hline Syysviljat Winter cereals & 4.7 & 2.9 & 2.4 & 3.0 & 4.6 & 8.8 & 4.2 \\
\hline Kevätvehnä Spring wheat & 11.6 & 9.1 & 5.5 & 2.7 & 6.5 & 3.3 & 5.0 \\
\hline Ohra Barley & 3.7 & 3.4 & 6.7 & 11.8 & 8.3 & 16.9 & 10.8 \\
\hline Kaura Oats & 24.6 & 22.1 & 24.3 & 24.0 & 23.2 & 24.0 & 27.5 \\
\hline Seosvilja Mixed cereal & 2.1 & 3.4 & 2.6 & 0.8 & 0.1 & 0.4 & 1.4 \\
\hline $\begin{array}{l}\text { Syysrypsi Winter turnip rape } \\
\text { Peruna ja juurik. Potatoes }\end{array}$ & - & 3.6 & 5.5 & 8.2 & 5.9 & 0.8 & 0.9 \\
\hline and beets & 8.2 & 7.1 & 8.0 & 4.7 & 6.5 & 6.3 & 5.8 \\
\hline Nurmet Hay plants & 41.3 & 45.0 & 41.3 & 41.5 & 39.5 & 37.7 & 37.6 \\
\hline Muut kasvit Other plants & 2.3 & 2.2 & 1.8 & 1.3 & 1.4 & 1.8 & 1.0 \\
\hline Kesanto Bare fallow & 1.5 & 1.2 & 1.9 & 2.0 & 4.0 & - & 5.8 \\
\hline & 100 & 100 & 100 & 100 & 100 & 100 & 100 \\
\hline Koko peltoala ha & & & & & & & \\
\hline Total arable land ha & 166 & 176 & 178 & 178 & 178 & 177 & 177 \\
\hline
\end{tabular}

Kauraa korvaamaan käytetty ohra on yleensä antanut hyviä satoja, joskaan ne eivät aikaisemmin kauranviljelyyn käytetyillä happamilla suomailla ole nousseet määrällisesti kaurasatojen suuruisiksi. Lisäksi väittävät viljelijät myös obran eräissä paikoin v. 1955 kärsineen kaskaan vioituksesta. - Vuosina 1957 ja -58 saadut hyvät kaurasadot vaikuttavat ilmeisesti siihen, että peltoalan käyttö palaa tuhon vaivaamillakin alueilla lähes ennalleen, ellei tuho esiinny voimakkaana lähi vuosina. 
Suomen läntisellä rannikkoseudulla viime vuosina esiintyneen (alligypona (Delphacodes) pellucidan aiheuttaman kaurantuhon symptomit saattavat eri vuosina vaihdella. V. 1957 oli tuhoutuneiden kaurojen väritys heikosti kellanruskea ja versominen vähäinen sekä sato parempi edelliseen vuoteen verrattuna.

Tuhoeläintutkimuslaitoksen tutkimusten sekä viljelijöiltä saatujen tietojen mukaan on uusien kaurantuhopaikkojen määrä vuoden 1955 jälkeen vähentynyt ja tuhon voimakkuudessa on vuoden 1955 jälkeen tapahtunut lievenemistä niin, että tuho oli vv. 1957 ja 1958 vaikeasti havaittavaa. Tuhon voimakkuus vaihtelee esiintymisalueellaan samana vuonna melkoisesti, johtuen ilmeisesti viljakaskaan lisääntymis-, säilymis- ja aikuistumispaikkojen määrästä eli etenkin suojaviljaan perustettujen 1.-vuoden heinänurmien osuudesta koko viljakasvialasta. Vuodesta 1955 lähtien tapahtunut tuhon voimakkuuden väheneminen johtunee 1) viljakaskaan populatiotiheydessä tapahtuneesta laskusta ja 2) tuhon ilmenemiseen vaikuttavista ulkoisista tekijöistä mm. kosteudesta ja lämmöstä.

Kaurantuhon satoa alentava ja pellon käyttöä muuttava vaikutus ilmenee Pohjanmaan maanviljelysseurojen sekä ko. alueen kirjanpitotilojen sato- ja viljelyalatilastoissa. Österbottens svenska lantbrukssällskap'in alueella oli kauranviljelyala v. 1956 vain $1 / 6$ v. 1954 alasta ja saman alueen kirjanpitotiloilla on kauran viljely lopetettu kokonaan.

Viljelijät ovat kauranviljelyn lopetettuaan tai sitä vähennettyään siirtyneet joko seosviljan kautta tai suoraan ohran viljelyyn sekä laajentaneet täyskesantoalaansa. Vuosina 1957 ja -58 saadut hyvät kaurasadot vaikuttanevat kauranviljelyalan palaamiseen lähes ennalleen, ellei voimakasta tuhoa esiinny lähi vuosina.

Kaurantuhon esiintymisessä on havaittavissa selvä yleistyminen vuodesta 1948 vuoteen 1955, jonka jälkeen tuho vuoteen 1958 mennessä näyttää melkoisesti lieventyneen ja lähes kadonneen. Kaurantuhon aikaisemmasta esiintymisestä Suomessa vuotta 1948 edeltäneeltä ajalta ei ole tietoja.

(1) Berger, J.-O. 1955. Havreodlingens dilemma. Redogörelse över Svenska lantbrukssällskapens i Finland förbunds verksamhet under àr 1954. s. $78-80$.

(2) —- 1955. Fritflugan — ett allvarligt hot mot havreodlingen. Österbottens svenska lantbrukssällskaps femtioförsta årsbok 1954. s. 81-82.

(3) Heıкınнermo, O. 1956. Disk. in Erik Johansson: Bollnässjukan, Nord. jordbr. forsk. 38 : 423.

(4) —- 1956. Viljakaskas Delphacodes pellucida F. kaurantuhon aiheuttajana (Delphacodes pellucida F. als Verheerer von Hafer). Ann. ent. fenn. 22: 184, 187.

(5) _... 1957. Uber Wiesenzirpe Delphacodes pellucida F. (Hom., Auchenorrh.) als Haferschădling in Finnland. IV Intern. Pfl. schutz-Kongress 1957. Kurzfassungen der Vorträge. s. 116 117.

(6) Jamalainen, E. A. 1957. Virustaudeista ja virustautien kaltaisista kasvitaudeista Suomessa. Valt. maatal.koetoim. julk. 158: $1-58$. 
(7) KANervo, V. 1957. Kaurantuhoista läntisellă rannikkoalueellamme. Maatalous 50: $173-176$.

(8) $\rightarrow$ 1958. Kaurantuhotutkimuksesta. Maatal. ja koetoim. 12: 118-131.

(9) $\longrightarrow$ 1958. Om havremissväxten i Österbotten. Sv. lantbr. sällsk. i Finland förb. Serie B 20; $1-20$.

(10) $\longrightarrow$ Heikinheimo, O., Raatikainen, M. and Trnnilä, A. 1957. The leafhopper Delphacodes pellucida (F). (Hom., Auchenorrhyncha) as the cause and distributor of the damage to oats in Finland. Valt. maatal.koetoim. julk. 160: 1-56.

(11) Nuorteva, P. 1958. On the nature of the injury to plants caused by Calligypona pellucida (F.) (Hom., Areopidae). Ann. ent. fenn. 24: 49-59.

(12) SömermaA, K. 1957. Statens Växtskyddsanstalts undersökningar rörande den s.k. Bollnässjukan i Hälsingland år 1956. Tidskr. hushàlln.sällsk. o. skogsv.styr. i Gävleborgs län. 33: 75-80.

(13) Tinnıl Ä, A. 1957. Havresjukan i Finland. Jord-Gröda-Djur. 1958. s. 176-178.

(14) $\longrightarrow$ 1957. Läntisen rannikkoseudun kaurantuhoista. Koetoim. ja käyt. 14: 18.

(15) VAlle, O. ja PaAtela, J. 1958. Niittonurmemme ja niiden kehittämistoimenpiteet. Pellervo 7 : $243-262$.

(16) Suomen virallinen tilasto: III 45: 1 ja 2 , 1954; III 46, 1955; III 47, 1956; III 48, 1957 ; III 49, 1957; III 50, 1958. Helsinki.

\section{S U M M A R Y :}

THE EFFECT OF THE DAMAGE TO OATS CAUSED BY CALLIGYPONA PELLUCIDA F. ON THE ACREAGES AND YIELDS OF OATS IN FINLAND

Mikko RaAtikainen and Aulis Tinnilä

Agricultural Research Centre, Department of Pest Investigation, Tikkurila

The damage to oats caused by Calligypona (Delphacodes) pellucida F. established in Finland, has previously been discussed in many publications (1-11, 13 and 14) The material of this study is composed of the investigations at the Department of Pest Investigation, of the informations given by farmers and of the agricultural statistics.

KANERvo et al. (10) have previously described the symptoms of the damage to oats. The damaging of oats to various degrees seems to be due to the grouping of $C$. pellucida on certain oats plants and to the constancy of these groups on the same plants. The oats plants of an earlier developmental stage are damaged more seriously and the severity of damage makes a positive correlation to the number and sucking-time of $C$. pellucida.

The symptoms vary depending on the habitat and the year. In 1957, for example, the colour of the oats damaged by $C$. pellucida was more slightly yellowish brown or red than in the previous year both in the field and in the isolation cage experiments. Accordingly the number of basal and lateral shoots was smaller and the yields better.

The area of damage extended rapidly until the year 1954, as the figures 2 and 3 indicate. After the peak of the years 1954 and 1955 the extension seems to slacken. The distribution area and the severity of damage estimated are presented in figure 4. The damage borders on a healthy tract with little arable land in the north and it is slightest in the barren watershed of Suomenselkä with dispersed farms and in the sandstone tract of the river Kokemäki.

Calligypona pellucida lives in the grass biotopes, as in cereals, grass, crops, meadows and swamps. The species increases mainly on cereals, and the grass, usually timothy, sown to cereals is the most important food plant of the nymphs. Theorethically it is to be concluded: 1 . The more cereals the more favourable places for reproduction of $C$. pellucida. 2 . The more crops layd on the cereals the better possibilities for the cicadas to emerge. The larger the ratio $(\mathrm{H})$ between the area of the lst year leys layd on the crops and the cultivated area of crops the more cicadas can be expected to occur per the area of 
crops and the more sever the damage will be. The ratio $\mathrm{H}$ in table 1 was calculated of the areas of some agricultural societies (cf. fig. 8). In drawing conclusions on the basis of the ratio $\mathrm{H}$, the old leys and berms, too, must be taken with. The ratio between the areas of the 1st year leys and those of the older ones on the tracts in question is about $1: 3.2$. The observations made in 1956 indicate that the nymphs occur more abundantly in the areas with high ratio $\mathrm{H}$. The calculations on the number of eggs done at the areas of the agricultural societies 1 and 3 (see figure 8) point to the same direction. The severity of damage shows also the same tendency (fig. 5). The example in table 2 indicates the percentage of destroying of the nymphs in the increasing biotopes of $C$. pellucida, treated in different ways at the area. About $45-60$ per cent of the grain fields situated at the area of damage and about $60-75$ per cent of the grain fields situated near this area became ploughed in autumn 1949 or in the next spring. The situation possibly continuing as this may on its part explain the territorial fluctuation in abundance of $C$. pellucida and the retarded extension of the area of damage and the moderating of damage towards the inland.

The better oats yields in 1957 (compared with that in the previous year) is partly due to the decreasing abundance of $C$. pellucida. In spring 1956 , on an average 927 nymphs $/ \mathrm{m}^{2}$ were stated in 11 1st year timothy grasslands obtained in sucking samples $\left(3 \times 0.10 \mathrm{~m}^{2}\right)$, in spring 1957 only $163 \mathrm{nymphs} /$ $\mathrm{m}^{2}$ as an average of 13 observation places. The number of egg groups (on an average 10.9 eggs per a group) per 100 plants in 11 observation places was 42.5 in 1956 and 22.3 in 1957 . The second reason is the more late swarming of $C$. pellucida in 1957 in regard to the developmental stage of oats. For the third the severity of damage is effected by some other factors, for the present less known (e.g. temperature and humidity) or unknown.

The effect of damage on the yields and acreages of oats appears in the agricultural statistics drawn up by the agricultural societies (16). The area 1 entirely belongs to the areas of damage as well as some parts the areas $2,3,4$ and 5 (see figures 4 and 8). The yields of oats per hectare appear in figure 6 and the deviation of annual yields from the average yields of a period of eight years in table 3 . The yield of oats per hectare at the area 1, was about $600 \mathrm{kgs}$ in 1954 , about $800 \mathrm{kgs}$ in 1955 and about $700 \mathrm{kgs}$ in 1956 smaller than the average yield of the whole country. The differences between the actual yield and the theoretical yield at the area of the agricultural society mentioned before appear in table 4 . The yields in 1957 were rather good. No great exceptions between the yields of the area of damage and the yields of the area of the other agricultural societies were not to be stated. The slight yields in the three first mentioned areas of the agricultural societies are due either to the unfavourable weather conditions (in 1952) or to the damage caused by C. pellucida (in 1955) or by the combined influence of both factors mentioned above (in 1954 and 1956). The numbers in table 5 a present the sale of the oats in a cooperative concern at Vähäkyrö (Vähänkyrön osuuskauppa). The number show the financial losses caused by the damage.

The slight yields caused by $C$. pellucida resulted to the reduction of the acreage of oats (fig. 7.) The acreage of oats at the area of the agricultural society, in 1956 was only $1 / 6$ from the acreage in 1954. The oats cultivation was wholly given up in the book-keeping farms of the same area (table 6).

A good conception of what the use of the acreage is like at the areas of damage and which are the plants cultivated when the area of oats decreased is given by the book-keeping farms. They were grouped in three groups according to their location at the area of damage (I, II and IV). In addition to these there were for comparison two farm-groups III and $\mathrm{V}$ where no damage occurred (cf. figure 8 ) .

The tables 6-10 clear up the proportion of the different cereals from the arable land. Giving up or lessering the oats cultivation the farmers proceeded to cultivate barley either directly or through the mixed crop of cereals. Accordingly they extended the area of bare fallow.

The good yields of oats in 1957 and 1958 obviously will effect on that the use of arable land will return to the former state also at the areas of damage in case the damage will not occur severely in the following few years.

There are no informations on the occurrence of damage in Finland before the year 1948. 